\title{
Peran Efikasi Diri dalam Memediasi Hubungan antara Keterlibatan Orang Tua dan Motivasi Berprestasi
}

\author{
Kumala Ayu Wardani $^{(1)}$, Iswinarti ${ }^{(1)}$, Diah Karmiyati ${ }^{(1)}$ \\ ${ }^{(1)}$ Fakultas Psikologi, Universitas Muhammadiyah Malang, Malang, Indonesia \\ Achievement motivation is very important for students because it is the driving force that enables \\ them to achieve what they desire. Parental involvement becomes one factor that influences \\ achievement motivation. The purpose of this study was to examine the relationship between parental \\ involvement and achievement motivation as mediated by self-efficacy. Among a sample of 200 junior \\ high school students, using a quantitative approach, data in the current research showed that self- \\ efficacy significantly mediated the relationship between parental participation and achievement \\ motivation.
}

Keywords: self-efficacy, parental participation, achievement motivation

\begin{abstract}
Motivasi berprestasi sangat penting bagi siswa karena motivasi berprestasi berperan sebagai daya dorong yang memungkinkan mereka mencapai apa yang mereka cita-citakan. Keterlibatan orang tua menjadi salah satu faktor yang mempengaruhi motivasi berprestasi. Tujuan dari penelitian ini adalah untuk menguji peran efikasi diri dalam memediasi hubungan antara keterlibatan orang tua dan motivasi berprestasi. Sampel atau subjek penelitian dalam penelitian ini adalah 200 siswa sekolah menengah pertama. Menggunakan pendekatan kuantitatif, data dalam penelitian ini menunjukkan bahwa efikasi diri berperan signifikan dalam memediasi hubungan antara keterlibatan orang tua dan motivasi berprestasi.
\end{abstract}

Kata kunci: efikasi diri, keterlibatan orang tua, motivasi berprestasi

MEDIAPSI, 2019, Vol. 5(2), 74-87, DOI: https://doi.org/10.21776/ub.mps.2019.005.02.2

Received: 2019-03-20. Revised: 2019-09-07. Accepted: 2019-11-12. Published online: 2019-12-05

Handling Editor: Ali Mashuri, Universitas Brawijaya, Malang, Indonesia

*Corresponding author: Kumala Ayu Wardani, Fakultas Psikologi, Universitas Muhammadiyah Malang, Malang,

Indonesia. E-mail: Ephilia01@gmail.com

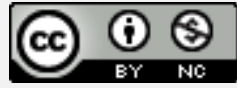

This work is licensed under a Creative Commons Attribution-NonCommercial 4.0 International License.

How to cite this article in accordance with the American Psychological Association (APA) $6^{\text {th }}$ guidelines:

Wardani, K. U., Iswinarti., \& Karmiyati, D. (2019). Peran efikasi diri dalam memediasi hubungan antara keterlibatan orang tua dan motivasi belajar. MEDIAPSI, 5(2), 74-87. DOI: https://doi.org/10.21776/ub.mps.2019.005.02.2

\section{Pendahuluan}

Dunia pendidikan dewasa ini mengharapkan dapat menghasilkan lulusan yang berkualitas dan memiliki kemampuan dalam keilmuan, keimanan, serta moralitas. Selama proses pembangunan pendidikan di Indonesia, permasalahan pendidikan Indonesia yang masih sering dihadapi adalah rendahnya mutu pendidikan pada setiap jenjang pendidikan, khususnya pendidikan dasar dan juga menengah. Berdasarkan Education Index yang dikeluarkan oleh Human Development Reports pada tahun 2017, Indonesia berada pada posisi ke-7 di ASEAN dengan skor 0.622 (Gerintya, 2019) dimana capaian ratarata lama sekolah pendidikan Indonesia masih di umur 15 tahun atau usia SMP.

Keberhasilan pendidikan yang ada di Indonesia tidak terlepas dari motivasi berprestasi siswa sehingga siswa dapat berprestasi dan menyelesaikan dengan baik suatu jenjang pendidikan. Berdasarkan hasil 
wawancara peneliti terhadap guru-guru yang dijadikan tempat pengambilan data, dapat disimpulkam bahwa dorongan motivasi berprestasi siswa di sekolah cenderung biasa saja, dimana siswa tidak memiliki kebiasaan belajar yang teratur dan mudah bosan ketika belajar. Kondisi rendahnya motivasi itu membawa akibat pada rendahnya kompetensi yang dikuasai siswa, yang pada gilirannya mengundang munculnya praktik-praktik curang dalam ujian. Motivasi berprestasi adalah daya dorong yang memungkinkan seseorang berhasil mencapai apa yang diidamkan. Penelitian tentang motivasi berprestasi terus dikembangkan oleh para ahli, terutama pada ranah psikologi pendidikan dan perkembangan. Motivasi berprestasi telah dipandang sebagai konstruk psikologis tradisional, yang telah dikembangakan sejak lama dalam penelitianpenelitian psikologi (Bempechat \& Shernoff, 2012). Akan tetapi, penelitian-penelitian ini telah dilakukan hampir tiga dekade terakhir, sehingga masih dibutuhkan penelitian lain dari berbagai budaya, variabel, latar belakang yang berbeda (Wigfield dkk., 2015).

Teori motivasi berprestasi berusaha untuk menjelaskan pilihan tugas pencapaian siswa, seperti ketekunan dalam mengerjakan tugas-tugas sehingga siswa lebih semangat dalam menjalankan tugas dan selanjutnya dapat menyelesikan suatu jenjang pendidikan dengan baik (Eccles, Wigfield, \& Schiefele, 1998; Pintrich \& Schunk, 1996). Selama ini ada berbagai konstruk yang diajukan oleh para ahli teori motivasi untuk menjelaskan bagaimana motivasi dapat mempengaruhi pilihan, ketekunan, dan kinerja siswa di sekolah. Salah satu perspektif lama yang menggambarkan konsep motivasi adalah teori self-determination atau teori determinasi diri. Teori determinasi diri mendalilkan adanya suatu dasar kebutuhan psikologi yang lebih lengkap, yaitu kompetensi, kemampuan menjalin hubungan atau relasi dengan orang lain, dan pemilihan pemenuhan kebutuhan individu atau otonomi (Schunk, Pintrich \& Meece, 2012).
Kompetensi

digambarkan sebagai kebutuhan siswa untuk mendapatkan pengalaman positif yang mendorong mereka untuk terlibat dalam lingkungan yang efektif. Kompetensi melibatkan pemahaman bagaimana siswa dapat mencapai hasil eksternal dan internal yang dijadikan landasan dalam pengambilan tindakan untuk lebih beprestasi (Green, Nelson, Martin, \& Marsh, 2006). Relasi merupakan kebutuhan seseorang untuk saling mendukung dalam hubungan antar individu di lingkungan tempat tinggal (Deci \& Ryan, 2000). Siswa membutuhkan keterkaitan dengan beberapa pihak yang ada di sekelilingnya seperti orang tua, guru, dan teman-teman untuk menunjang motivasi berprestasinya di sekolah dengan menjalin hubungan serta komunikasi yang baik (Gagne \& Deci 2005). Dorongan dari luar individu memiliki fungsi agar siswa dapat lebih optimal dalam menyelesaikan pemenuhan kebutuhan dan menjadi sumber motivasi eksternal (Moller, Friedman, \& Deci, 2006). Otonomi mencerminkan tindakan siswa atas inisitif mereka sendiri sendiri setelah merasakan berbagai pengalaman-pengalaman yang mereka lalui dalam proses belajar di sekolah. Ketika siswa sudah terbiasa mandiri, saat menjalani suatu kegiatan mereka merasa tertarik dan melakukan kegiatan tersebut sepenuhnya karena kemauan mereka sendiri.

Motivasi sebagai keyakinan untuk berprestasi dinilai dapat mempengaruhi siswa dalam menafsirkan atau memberikan makna dari setiap pengalaman untuk mencapai prestasi di sekolah. Keyakinan untuk berprestasi dianggap sebagai bagian terpenting bagi siswa untuk dapat mempengaruhi perilaku yang ditujukan untuk meraih prestasi di sekolah (Bempechat \& Shernoff, 2012). Sebagai contoh, jika siswa percaya bahwa kemampuan yang dimiliki biasa saja maka siswa akan memiliki kecenderung untuk menghindari tugas yang menantang. Sebaliknya, jika siswa memandang bahwamereka mampu bersaing dengan siswa lainnya maka siswa tersebut akan siap 
menerima tugas yang diberikan (Dweck, 2006). Siswa yang memiliki motivasi berprestasi tinggi akan menunjukkan kegigihan dan antusiasme yang tinggi. Sebaliknya, siswa yang kurang memiliki motivasi berprestasi akan memperlihatkan usaha untuk menghindari kegiatan di sekolah (Wigfield \& Eccles, 2000). Siswa dengan motivasi berprestasi tinggi sering menilai dan mengukur kemajuan yang telah dicapai. Siswa tersebut menetapkan tujuan dan bersedia mengambil resiko yang menantang namun realistis (Uduji \& Ankeli, 2013). Siswa dengan motivasi berprestasi yang tinggi memiliki ciri-ciri antara lain tidak takut menghadapi kegagalan, bertanggung jawab dalam bertindak, memiliki keinginan untuk menghadapi tugas-tugas yang menantang, mampu menetapkan tujuan jangka panjang, serta dapat memfokuskan diri pada pekerjaannya (Schuler, Thorton, Frintrup, \& Mueller-Hanson, 2002). Ketika siswa sudah melakukan suatu kegiatan sekolah, motivasi dapat mempengaruhi seberapa rajin siswa tersebut melakukan suatu aktivitas dan bagaimana mereka mencapai kegiatan sekolah. Para ahli teori motivasi berprestasi telah meneliti tentang bagaimana memprediksi dan memahami motivasi. Tujuannya adalah untuk mengetaui sejauhmana motivasi dapat mempengaruhi siswa dalam melakukan pilihan kegiatan sekolah yang tepat, serta berusaha dan terlibat dalam menjalankan tugas dan aktivitas terkait prestasi di sekolah (Eccles dkk., 1998).

Motivasi berprestasi dapat dipengaruhi oleh berbagai macam faktor, yang bersumber baik diri siswa sendiri dan dari lingkungan belajar (Kusurkar, Cate, Asperen \& Croiset, 2011). Sebuah model hirarki motivasi menjelaskan bahwa motivasi berprestasi memiliki faktor-faktor penyebab yang dapat dimanipulasi maupun tidak dapat dimanipulasi. (Vallerand \& Ratelle, 2004). Faktor dukungan orang tua menjadi salah satu faktor yang tidak bisa dimanipulasi. Selain itu, sebuah penelitian kualitatif menunjukkan bahwa dukungan orang tua memiliki efek positif terhadap motivasi berprestasi (McHarg, Mattick, \& Knight, 2007).

Orang tua adalah agen sosialisasi utama dalam kehidupan siswa. Kebutuhan siswa sehari-hari sangat tergantung pada sejauh mana orang tua mampu menciptakan konteks yang memuaskan kebutuhan mereka. Orang tua mempengaruhi anak di sejumlah domain termasuk perkembangan sosial dan juga penyesuaian perilaku, sehingga orang tua memiliki peran penting dalam pengalaman sekolah anak-anak (Grolnick, 2016). Efikasi diri menjadi konstruk yang menarik bagi para ahli teori motivasi sampai saat ini. Efikasi diri mencerminkan adanya harapan untuk sukses, keyakinan diri sendiri untuk berhasil mengatasi segala rintangan. Dengan efikasi diri, individu meyakini bahwa diri mereka mampu merealisasikan segala tujuan belajar, mengembangkan minat, motivasi intrinsik dan prestasi di sekolah (Bandura, 1997; Eccles, 2005; Maehr \& Zusho, 2009; Schiefele, 2009).

Ketika siswa menghadapi tugas akademik, siswa akan bertanya kepada diri sendiri tentang kemampuan menyelesaikan tugas di sekolah dan alasan mengapa harus menyelesaikan tugas tersebut. Efikasi diri dianggap sebagai modal untuk menyelesaikan sebuah tantangan dan sebagai sumber motivasi internal yang penting sehingga mampu mengaktifkan motivasi siswa pada tahap pertama proses tingkah laku. Efikasi diri dilaporkan memiliki kontribusi besar dalam mengaktifkan motivasi siswa sejak mingguminggu pertama dalam proses belajar mengajar yang dilakukan pada mata pelajaran tertentu (Doménech-Betoret, Abellán-Roselló, \& Gómez-Artiga, 2017). Selain itu, motivasi juga dapat menjadi mediator dari efikasi diri (Bong, Cho, Ahn, \& Kim, 2012; Doménech-Betoret dkk., 2017). Efikasi diri juga mencerminkan kemampuan seseorang untuk mengelola emosi negatif terkait dengan stres dan emosi yang dapat mengakibatkan ketakutan dan kecemasan yang terkadang tidak disadari seperti rasa 
bersalah dan juga rasa malu (Caprara, Pastorelli, \& Einsenberg, 2013).

Emosi-emosi negatif tersebut tidak jarang akan muncul ketika siswa menjalani proses kegiatan sekolah. Hal ini disebabkan karena di sekolah ada begitu banyak tantangan dimana siswa harus mampu menyesuaikan tantangan tersebut dengan kemampuan yang dimiliki. Efikasi diri memainkan peran penting dalam meningkatkan harapan siswa seperti pencapaian prestasi dan perasaan postif dalam menjalani proses belajar (Doménech-Betoret, Gómez-Artiga, \& Lloret-Segura, 2014). Penelitian yang kami lakukan adalah yang pertama dimana kami menguji peran efikasi diri dalam memediasi hubungan antara keterlibatan orang tua dan motivasi berprestasi.

Peran keterlibatan orang tua sebagai significant other bagi siswa memiliki tujuan untuk menumbuhkan efikasi diri. Faktor orang tua juga memiliki efek terhadap efikasi diri siswa (Gonzalezz-DeHass, Willems, \& Holbein, 2005). Hal ini terjadi karena pengaruh orang tua berada pada sistem sosial siswa, yang kemudian akan membentuk sebuah interaksi pengasuhan. Orang tua tidak hanya mempengaruhi perkembangan efikasi diri tetapi juga memiliki keterlibatan dalam memandu penyesuaian siswa terhadap efikasi diri (Bandura, 1997). Peran orang tua yang merupakan faktor dari lingkungan, tidak hanya mempengaruhi apa yang dipikirkan individu tapi juga apa yang akan dilakukan siswa (Schunk \& Zimmerman, 2006). Keterlibatan orang tua menggambarkan sejauh mana orang tua mampu dalam mendedikasikan waktunya, tertarik, dan secara aktif berpartisipasi dalam proses akademik siswa di sekolah. Keterlibatan orang tua secara lebih spesifik memiliki tiga dimensi yaitu keterlibatan perilaku, keterlibatan pribadi, dan keterlibatan kognitif (Hoang, 2007).

Lingkungan sosial juga mampu mempengaruhi perilaku remaja dan efikasi diri melalui pengalaman belajar dimana remaja memiliki perwakilan dan komunikasi yang bersifat mendukung (Bandura, 1997). Aspirasi orang tua dapat menunjang tidak hanya perkembangan motivasi akademik siswa akan tetapi juga perkembangan sosial dan emosional mereka di sekolah. Aspirasi pendidikan orang tua terejawantah ketika orang tua mampu memperhatikan siswa ketika berada di rumah. Sikap ini dapat meningkatkan kualitas hubungan orang tua-anak ( $\mathrm{Lv}$ dkk, 2018). Selain itu, pola hubungan yang baik ini dapat berkembang ke lingkungan sosial di luar rumah, sehingga anak-anak dapat merasakan efikasi diri yang lebih tinggi. Penelitian sebelumnya juga menyarankan bahwa tanggung jawab orang tua terhadap pendidikan siswa dapat meningkatkan fungsi emosional anak-anak di sekolah (Wang \& Eccles, 2012).

Angka Partisipasi Sekolah (APS) menjadi salah satu tolak ukur pendidikan Indonesia dalam melihat seberapa besar masyarakat mengenyam pendidikan. Sebagai contoh, data di Kabupaten Magetan dimana penulis mengambil penelitian, menunjukkan APS sebesar $92.82 \%$ pada siswa SMP berusia 13 sampai 15 tahun. Angka tersebut menurun jika dibandingkan dengan tahun 2010 dimana APS Kabupaten Magetan naik sebesar 97.57\%. Sebesar $4.75 \%$ masyarakat berusia 13 tahun sampai 15 tahun Kabupaten Magetan, dengan demikian, diindikasikan tidak mengenyam pendidikan hingga tamat SMP (Badan Pusat Statistik Magetan, 2016).

Berdasarkan pemaparan yang telah dijelaskan, rumusan masalah dalam penelitian ini adalah 'apakah keterlibatan orang tua dapat mempengaruhi motivasi berprestasi'. Permasalahan penelitian kedua adalah 'apakah efikasi diri berperan signifikan dalam memediasi hubungan antara keterlibatan orang tua dan motivasi berprestasi siswa'. Atas dasar dua permasalahan ini, penelitian ini bertujuan untuk mengetahui sejauhmana hubungan antara keterlibatan orang tua dan motivasi berprestasi siswa dimediasi oleh efikasi diri siswa.

Manfaat yang diharapkan oleh penelitian ini terbagi menjadi dua, yaitu manfaat teoritis 
dan manfaat praktis. Manfaat teoritis terkait dengan harapan bahwa penelitian ini mampu memberikan sumbangan teoritis untuk menambah pengetahuan tentang motivasi berprestasi. Manfaat praktis dari hasil penelitian ini adalah bahwa orang tua dapat mengetahui bagaimana keterlibatannya dalam mempengaruhi motivasi berprestasi dan kepercayaan diri pada siswa di sekolah sehingga dapat memberikan hasil yang memuaskan pada hasil akademik siswa.

Efek mediasi efikasi diri pada hubungan keterlibatan orang tua dan motivasi berprestasi dapat dijelaskan melalui keterlibatan orang tua dalam pendidikan individu siswa yang dapat mempengaruhi performa individu siswa di sekolah. Orang tua dapat hadir dengan menjalin komunikasi yang hangat dalam mendiskusikan proses apa saja yang dilalui siswa di sekolah. Adanya keterlibatan orang tua atas pendidikan anak mereka di sekolah akan memiliki keuntungan dalam performa dan motivasi berprestasi di sekolah (Gonzalez-DeHass dkk., 2005). Jika orang tua sudah terlibat dalam proses belajar siswa, maka siswa akan lebih baik dalam peforma belajar di sekolah. Orang tua akan mencurahkan perhatiannya dengan berdiskusi dan memberi saran bagaimana langkah yang baik dalam menyelesaikan tantangan-tantangan tugas di sekolah dengan memberi kepercayaan bahwa individu siswa dapat menyelesaikan tantangan-tantangan tersebut. Komunikasi yang efektif dan pemberian contoh yang baik dari orang tua dapat meningkatkan motivasi berprestasi siswa.

Komunikasi antara anak dan orang tua merupakan salah satu aspek terbentuknya sikap keterlibatan orang tua terhadap kegiatan siswa. Komunikasi yang dibangun ketika orang tua terlibat dalam kegiatan siswa adalah orang tua sering menanamkan nilai-nilai kepada siswa saat di rumah. Komunikasi akan efektif dan tepat jika orang tua juga terlibat dalam kegiatan yang dilakukan siswa (Hill \& Taylor, 2004). Dengan kata lain, orang tua tidak hanya menyarankan sebuah cara menjalani sebuah kegiatan sekolah tetapi juga memberikan contoh dan meluangkan waktu untuk memahami kebutuhan siswa, sehingga siswa mau mendengarkan orang tua, yang akan menjadi awal dari penerimaan nilai yang ditanamkan oleh orang tua (Antawati, 2017).

Motivasi berprestasi yang baik tidak terlepas dari pengaruh efikasi diri pada diri individu siswa. Dorongan untuk lebih berprestasi dimulai dengan keyakinan dari diri siswa bahwa mereka mampu menyelesaikan berbagai tantangan yang diberikan. Berbekal keyakinan ini, ketika merasa belum maksimal dalam menyelesaikan tantangan, siswa tidak mudah menyerah karena masih memiliki motivasi untuk lebih berprestasi lagi. Efikasi diri dapat mendukung motivasi dan perkembangan kemampuan berprestasi siswa di sekolah (Klassen \& Usher, 2010).

Efikasi diri merupakan salah satu kemampuan individu siswa untuk lebih dapat percaya akan kemampuan dirinya sendiri sehingga dapat mempengaruhi performa individu dalam berprestasi di sekolah. Keterlibatan orang tua akan menjadi cara untuk mendapatkan keyakinan individu siswa dengan melibatkan komunikasi yang baik dan menjadi role model sehingga dapat memperlihatkan motivasi berprestasi yang baik di sekolah.

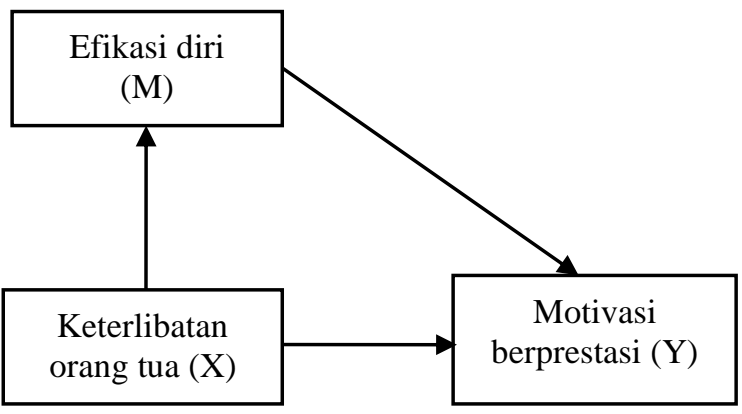

Gambar 1. Kerangka berpikir dalam penelitian ini. Keterangan: $\mathrm{X}=$ variabel independen; $\mathrm{M}=$ mediator; $\mathrm{Y}=$ variabel dependen.

Kerangka pemikiran dalam penelitian ini dirangkum dalam Gambar 1 di atas. Berdasarkan pada argumentasi-argumentasi teoretis dan temuan-temuan empiris sebagaimana telah dipaparkan di atas, peneliti menetapkan empat hipotesis. Pertama, 
keterlibatan orang tua berkorelasi positif dengan motivasi berprestasi pada siswa (Hipotesis 1). Kedua, keterlibatan orang tua berkorelasi positif dengan efikasi diri (Hipotesis 2). Ketiga, efikasi diri berkolerasi posiitif dengan motivasi berprestasi pada siswa (Hipotesis 3). Keempat, efikasi diri memediasi hubungan keterlibatan orang tua dengan motivasi berprestasi siswa (Hipotesis 4).

\section{Metode}

\section{Desain penelitian}

Rancangan penelitian ini dilakukan dengan metode ex post factory one shot design. Rancangan penelitian ini dipilih karena penelitian ini tidak memberikan perlakuan pada sampel karena data sudah tersedia. Analisis dalam penelitian ini menggunakan analisis regresi. Analisis regresi digunakan untuk membuktikan keterkaitan antar variabel dan nilai mediasi (Creswell, 2014).

\section{Partisipan}

Penelitian ini akan menguji efikasi diri sebagai variabel mediator dalam hubungan antara keterlibatan orang tua dan motivasi berprestasi siswa. Sebagaimana ditampilkan pada Tabel 1, penelitian ini menggunakan responden sebanyak 200 siswa sekolah menengah pertama Kelas V, VII, dan VIII yang sedang mengikuti proses belajar mengajar di sekolah. Teknik pengambilan sampel adalah quota sampling, yaitu teknik untuk menentukan sampel dari populasi yang mempunyai ciri-ciri tertentu sampai jumlah (kuota) yang diinginkan (Clark-Carter, 2010).

Penelitian ini diawali dengan tahapan persiapan yaitu mempersiapkan instrumen untuk mengukur motivasi berprestasi, keterlibatan orang tua, dan efikasi diri. Peneliti melakukan uji coba instrumen untuk mengukur nilai reliabilitas, lalu peneliti melakukan screening awal untuk menetapkan subjek penelitian sesuai dengan kriteria khusus yang telah ditetapkan pada penelitian ini, yaitu remaja awal berusia 11 sampai 15 tahun yang sedang mengikuti kegiatan sekolah dan memiliki orang tua lengkap. Selanjutnya peneliti memberikan kuesioner langsung kepada partisipan.

Jumlah keseluruhan kuesioner yang disebarkan sebanyak 315. Setelah kuesioner terisi selanjutnya peneliti menyeleksi subjek berdasarkan kriteria khusus yang telah ditetapkan. Selanjutnya peneliti melakukan tabulasi data, menganalisis distribusi hasil penelitian, dan melakukan uji hipotesis. Tahap terakhir adalah memberikan kesimpulan dari hasil analisis data.

Tabel 1. Data Demografis Responden $(N=200)$.

\begin{tabular}{lll}
\hline Uraian & Jumlah & Persentase \\
\hline Sekolah & & \\
SMP Negeri 1 Bendo & 100 & $50 \%$ \\
SMP Negeri 2 Keraton & 50 & $25 \%$ \\
MTSN Takeran & 50 & $25 \%$ \\
Jenis Kelamin & & \\
Laki-Laki & 90 & $45 \%$ \\
Perempuan & 110 & $55 \%$ \\
Usia & & \\
11 Tahun & 5 & $3 \%$ \\
12 Tahun & 70 & $35 \%$ \\
13 Tahun & 61 & $31 \%$ \\
14 Tahun & 60 & $30 \%$ \\
15 Tahun & 5 & $3 \%$ \\
\hline
\end{tabular}

\section{Instrumen penelitian}

Peneliti menggunakan tiga macam instrumen. Instrumen pertama adalah Academic Motivation Scale High School Version. Skala ini dirancang oleh peneliti dengan mengacu pada variabel motivasi berprestasi yang sebelumnya dikembangkan oleh Vallerand, Blais, Biere, Senecal, dan Vallieres (1992). AMS memiliki 24 item. AMS pertama kali disusun oleh Vallerand dan koleganya dalam bahasa Perancis dengan nama Echele de Motivation en Education (EME) di tahun 1989. Selanjutnya, Vallerand dkk. (1992) melakukan adaptasi EME ke dalam Bahasa Inggris sehingga menjadi AMS (Marvianto \& Widhiarso, 2018). AMS terdiri dari 24 butir pernyataan yang mengukur tujuh jenis motivasi. Ketujuh jenis motivasi tersebut merupakan turunan dari dua jenis motivasi, yaitu intrinsic 
motivation, extrinsic motivation, yang dilandaskan pada teori motivasi menurut self determination theory (Vallerand dkk., 1992). Ketujuh motivasi tersebut mencakup intrinsic motivation to know, intrinsic motivation toward accomplishment, intrinsic motivation to experience stimulation, external regulation, introjected regulation, dan identified regulation, serta satu tipe amotivation (Marvianto \& Widhiarso, 2018). AMS memiliki nilai reliabilitas Cronbach's alpha $(\alpha)$ sebesar 0.87 .

Instrumen selanjutnya adalah Parental Involvement Rating Scale (PIRS) yang dikembangkan oleh Gafoor (2015). PIRS dirancang untuk mengetahui persepsi siswa terhadap keterlibatan orang tua mereka dalam proses akademik siswa di sekolah. Skala PIRS merupakan kuesioner laporan diri dengan menggunakan format skala likert 1 (sangat tidak setuju) sampai 4 (sangat setuju). PIRS memiliki 42 item yang berisi 7 subskala. Parental acceptance terdiri dari 4 item yang menggambarkan sejauh mana orang tua menerima, menyetujui, memberikan toleransi dan bekerja sama dengan siswa dan kegiatan sekolah siswa. Parental aspiration terdiri dari 6 item yang menggambarkan aspirasi dan keinginan, harapan, niat, tujuan, dan ambisi yang diungkapkan orang tua terkait dengan kegiatan sekolah siswa. Parental attention terdiri dari 10 item yang menggambarkan tingkat perhatian, pertimbangan, kepedulian, dan pemberian tunjangan yang memadai dari orang tua terkait dengan kegiatan sekolah siswa. Parental encouragement terdiri dari 8 item yang menggambarkan dorongan, inspirasi, dan stimulasi yang diberikan oleh orang tua terkait dengan kegiatan sekolah siswa. Parental guidance terdiri dari 5 item yang menggambarkan sejauhmana orang tua siswa memberikan bantuan dalam kegiatan sekolah siswa. Parental influence terdiri dari 3 item yang menggambarkan sejauhmana orang tua memiliki pengaruh terhadap keputusan kegiatan sekolah siswa. Parental provision of physical facilities terdiri dari 1 item yang menggambarkan sejauhmana orang tua memberikan perhatian khusus terhadap kesehatan fisik anak. PIRS memiliki koefisisen Cronbach's alpha sebesar 0.84 .

Instrumen terakhir yang digunakan adalah Self-Efficacy Questionnaire for Children (SEQ-C; Muris, 2001). SEQ-C dirancang untuk mengetahui gambaran efikasi diri siswa dalam proses akademik siswa di sekolah. Skala SEQC merupakan kuisioner laporan diri dengan menggunakan format skala likert 1 (sangat tidak setuju) sampai 4 (sangat setuju). Ada 22 item di setiap subskala. Skala SEQ-C terdiri dari tiga subskala. Pertama adalah akademik efikasi diri yang terdiri dari 6 item yang menggambarkan kemampuan merasakan dalam mengelola perilaku berprestasi siswa. Kedua adalah sosial efikasi diri yang terdiri dari 7 item yang menggambarkan kemampuan merasakan dalam menjalin hubungan dengan teman sebaya. Ketiga adalah emosi efikasi diri yang terdiri dari 8 item yang menggambarkan kemampuan diri dalam mengatasi emosi negatif. SEQ-C memiliki konsistensi internal dengan koefisisen Cronbach's alpha sebesar 0.77 .

\section{Hasil}

\section{Statistik deskriptif}

Tabel 2 di bawah ini menampilkan statistik deskriptif rata-rata atau mean dan deviasi standar masing-masing variabel dalam penelitian ini, dilihat dari segi jenis kelamin (laki-laki dan perempuan).

Tabel 2. Mean dan Standar Deviasi Efikasi Diri, Motivasi Berprestasi, dan Keterlibatan Orang Tua Ditinjau dari Jenis Kelamin.

\begin{tabular}{llll}
\hline Variabel & $\begin{array}{l}\text { Motivasi } \\
\text { Berprestasi }\end{array}$ & $\begin{array}{l}\text { Efikasi } \\
\text { Diri }\end{array}$ & $\begin{array}{l}\text { Keterlibatan } \\
\text { Orang Tua }\end{array}$ \\
\cline { 2 - 4 } & $M(S D)$ & $M(S D)$ & $M(S D)$ \\
\hline Laki-Laki & $69.3(9.4)$ & $57.7(6.1)$ & $95.4(6.9)$ \\
Perempuan & $74.8(9.8)$ & $57.2(7.6)$ & $96.5(7.01)$ \\
\hline Keterangan: $M=$ mean; $S D=$ standar deviasi.
\end{tabular}

\section{Uji hipotesis}


Tabel 3 menampilkan statistik deskriptif rata-rata dan deviasi standar, serta korelasi antar variabel dalam penelitian ini. Hasil uji statistik menunjukkan bahwa terdapat hubungan positif dan signifikan antara keterlibatan orang tua dengan motivasi berprestasi $(\beta=0.31, p<$ 0.001), sehingga hipotesis pertama diterima. Terdapat hubungan yang positif dan signifikan antara keterlibatan orang tua dengan efikasi diri ( $\beta=0.19, p<0.001)$, sehingga hipotesis kedua diterima. Terdapat hubungan yang positif dan signifikan antara efikasi diri dengan motivasi berprestasi $(\beta=0.38, p<0.001)$, sehingga hipotesis ketiga dapat diterima.

Tabel 3. Mean, Standar Deviasi, dan Hubungan Antar Variabel $(N=200)$

\begin{tabular}{llrrrcc}
\hline & Variabel & $M$ & $S D$ & 1 & 2 & 3 \\
\hline 1 & KOT & 96.02 & 6.99 & - & $0.31 * *$ & $0.19 *$ \\
2 & MB & 72.39 & 9.99 & - & $0.38 *$ \\
3 & ED & 57.49 & 7.02 & & - \\
\hline Keterangan: $M=$ mean; & $S D=$ standar deviasi; & KOT $=$ keterlibatan \\
orang tua; ED $=$ efikasi diri. MB = motivasi berprestasi. & \\
$* * p<0.01 . * p<0.05$.
\end{tabular}

Analisis mediasi mengacu pada prosedur dari Hayes dan Preacher (2014). Nilai mediasi dalam penelitian ini diperoleh sebesar $\beta$ $=0.30$ dengan tingkat kepercayaan 95\% . Hasil Uji Sobel menunjukkan bahwa $Z=1.98>1.96$ (nilai $Z$ mutlak). Hasil dari uji model mediasi memiliki empat kondisi yaitu (1) variabel keterlibatan orang tua dengan motivasi berprestasi memiliki hubungan dan signifikan, (2) variabel keterlibatan orang tua dengan efikasi diri memiliki hubungan dan signifikan, (3) variabel efikasi diri dengan motivasi berprestasi memiliki hubungan dan signifikan, dan (4) nilai pengaruh langsung ( $c^{\prime}=0.24, p=$ 0.02) lebih kecil dibandingkan nilai pengaruh total $(c=0.31, p<0.001)$. Hal ini menunjukkan bahwa, mendukung hipotesis keempat, variabel efikasi diri memediasi secara parsial (sebagian) hubungan keterlibatan orang tua dan motivasi berprestasi yang dialami oleh siswa sekolah menengah pertama.

\section{Diskusi}

Hasil dalam penelitian ini menunjukkan bahwa keterlibatan orang tua memiliki hubungan yang positif dan sangat signifikan dengan motivasi berprestasi. Hal ini menunjukkan bahwa semakin tinggi keterlibatan orang tua berimplikasi pada semakin tinggi motivasi berprestasi siswa. Hasil penelitian ini diperkuat oleh penelitian yang dilakukan oleh Omar, Ahmad, Hassan, dan Roslan (2017) di Malaysia pada remaja akhir dimana keterlibatan orang tua secara signifikan berpengaruh positif terhadap motivasi berprestasi yang dimiliki oleh siswa.

Keterlibatan orang tua dalam proses belajar siswa memiliki tujuan memberikan perhatian penuh ketika berada di rumah, membantu siswa dapat menyelesaikan pekerjaan rumah dan selalu memastikan semua tugas yang diberikan oleh guru selesai dengan baik. Keterlibatan orang tua dalam pendidikan siswa membantu siswa meningkatkan motivasi dan mencapai tujuan baik dalam akademik maupun keterampilan mereka di sekolah. Keterlibatan orang tua memberikan kesan yang baik dan mengembangkan hubungan yang baik dengan guru di sekolah. Situasi ini akan mempengaruhi kolaborasi orang tua dan guru untuk mencapai keunggulan dalam pencapaian prestasi siswa di sekolah, yang selanjutnya membuat siswa lebih termotivasi dalam berprestasi (Charlotte, 2014).

Bentuk keterlibatan orang tua pada siswa remaja tidak sama seperti keterlibatan orang tua pada siswa anak-anak. Orang tua yang terlibat dalam proses belajar siswa remaja cenderung bertujuan menciptakan suasana yang hangat melalui diskusi, arahan, dan dukungan pada setiap kegiatan yang telah dipilih oleh siswa tersebut. Keterlibatan orang tua yang baik dalam proses belajar siswa akan mempengaruhi emosi dan motivasi siswa. Orang tua yang selalu membantu anak-anak mereka di rumah akan memotivasi siswa untuk mendapatkan hasil yang lebih baik dalam penilaian dari sekolah (Dumont dkk., 2012). Ketika orang tua melibatkan diri dalam konteks pendidikan, mereka akan menjadi sosok yang mempengaruhi emosi anak mereka (Pomerantz, 
Moorman, \& Litwack, 2007). Praktik keterlibatan orang tua yang dapat mengurangi tekanan emosi negatif siswa bisa melindungi siswa remaja dari kecemasan, memfasilitasi transisi sekolah yang lebih lancar, dan mendorong motivasi akademik siswa (Newman, Griffen, O'Connor, \& Spa, 2007; Pomerantz dkk., 2007). Transisi dari sekolah menengah pertama menuju sekolah menengah atas menciptakan situasi dan kondisi yang sangat menuntut secara emosional yang dapat mempengaruhi keinginan remaja. Situasi dan kondisi yang menantang ini bisa menimbulkan kontradiksi antara otonomi diri sendiri dan kebutuhan dukungan dari orang tua dalam proses belajar di sekolah (Eccles dkk., 2005).

Penelitian ini menemukan adanya hubungan positif antara efikasi diri dan motivasi berprestasi. Efikasi diri dalam akademik siswa dapat diwujudkan dari keyakinan individu siswa tentang kemampuan mereka untuk mendorong dan menggerakan motivasi berprestasi, sumber daya kognitif, dan cara untuk bertindak, yang diperlukan dalam menyelesaikan tugas dengan hasil yang baik. Efikasi diri pada kemampuan diri sendiri sangat dibutuhkan dalam proses mengerjakan dan menyelesaikan tugas, karena efikasi diri akan mempengaruhi daya upaya dan daya juang yang dilakukan individu siswa di sekolah. Kemampuan dan kapasitas siswa juga dapat menentukan tingkat optimisme dalam menyelesaikan tugas dengan tujuan agar dapat lebih berprestasi sehingga akan berdampak pada hasil belajar di sekolah. Efikasi diri akan memotivasi seseorang secara kognitif agar dapat bertindak lebih giat, serta didukung dengan tujuan yang jelas dalam pencapaianpencapaian berprestasi. Efikasi diri yang diwujudkan siswa dalam peforma mereka di sekolah dapat dimulai dari motivasi dari individu siswa, sehingga efikasi diri memiliki hubungan terhadap motivasi berprestasi (Schunk, 2003).

Keterlibatan orang tua dan efikasi diri pada penelitian ini menunjukkan hubungan yang positif dan signifikan. Praktik keterlibatan orang tua dalam proses belajar dibutuhkan siswa dalam menunjang efikasi diri siswa agar lebih baik. Para ahli efikasi diri menjelaskan bahwa semakin tinggi efikasi diri yang dimiliki individu, maka semakin banyak upaya dan ketekunan yang akan diwujudkan individu tersebut dalam pencapaian tugas-tugas yang menantang agar dapat mendapatkan hasil yang ingin dicapai (Bandura, 1989; Zimmerman, Bandura, \& Martinez-Pons, 1992).

Pada proses pencapaian siswa di sekolah, siswa memiliki upaya yang banyak agar dapat menyelesaikan capaian-capaian yang dibuat. Dalam proses tersebut siswa akan melibatkan orang lain untuk membantu dan menggambarkan hasil dari upaya dan tindakan mereka (Bandura, 1992). Keterlibatan orang tua akan menjadi salah satu cara untuk melibatkan orang lain dalam menunjang efikasi diri di sekolah, dimana orang tua akan menjadi salah satu figur yang dapat memberikan contohcontoh yang baik dalam kehidupan sehari-hari. Orang tua yang memberikan contoh-contoh yang baik secara natural akan membentuk lingkungan dan pengalaman sekitar pada siswa. Implikasinya, faktor penunjang efikasi diri siswa akan terbentuk dimana siswa akan mendapatkan insentif yang diberikan orang lain sehingga merefleksikan keberhasilan yang diraih oleh orang lain dan menerapkannya pada pengalaman siswa sendiri (Bandura, 1992).

Sebuah studi menunjukkan bahwa peran ayah dalam keterlibatan orang tua disekolah cenderung membantu siswa dalam mempersiapkan diri untuk masuk ke dalam kehidupan masyarakat (Kim \& Hill, 2015). Oleh karena itu, ayah lebih sering memiliki orientasi instrumental yang berfokus pada kinerja dan standar objektif. Kegiatan yang melibatkan ayah dan siswa, seperti mengunjungi museum atau terlibat dalam praktik sosial individu siswa, dapat memberikan kesempatan bagi ayah untuk membantu siswa dalam memahami dunia disekitar mereka. Dengan kesempatan ini, siswa 
dapat merasakan perhatian tulus dari ayah yang pada akhirnya dapat meningkatkan perkembangan fungsi emosional mereka (Lv dkk., 2018). Peran seorang ibu dalam keterlibatan orang tua di sekolah lebih fokus pada pemeliharaan dan pemberian dukungan emosional, sementara peran ayah cenderung lebih berfokus pada menyiapkan anak-anak mereka untuk masa depan (Jeynes, 2016). Selain itu, keterlibatan ibu berperan dalam meningkatkan perasaan harga diri, kompetensi persepsi akademik yang tinggi, dan motivasi yang tinggi pada siswa di sekolah (Grolnick, 2015).

Keterlibatan orang tua pada masa remaja awal akan berbenturan dengan isu kemandirian. Dilaporkan bahwa pada masa remaja, siswa remaja cenderung menjauhi orang tua mereka. Hal ini akan mempengaruhi performa belajar mereka di sekolah karena siswa remaja akan lebih membiarkan tugas yang menjadi target jika tidak ada sosok figur orang tua yang bertugas memantau proses belajar mereka (Peiffer, 2015). Keterlibatan orang tua dengan demikian akan berubah sesuai masa perkembangan anak-anak mereka. Dalam isu kemandirian remaja awal, tugas keterlibatan orang tua perlu mendapatkan dukungan dari pihak sekolah dimana pihak sekolah memberikan pengetahuan bagaimana menghadapi remaja akhir dan apa saja yang dibutuhkan oleh remaja akhir sehingga dapat menciptakan keterlibatan orang tua yang sesuai dengan masa perkembangan anak-anak mereka (Pomerantz dkk., 2007).

Penelitian ini juga menunjukkan bahwa efikasi diri memediasi secara parsial hubungan antara keterlibatan orang tua dan motivasi berprestasi. Motivasi berprestasi dapat dipengaruhi oleh keterlibatan orang tua dan efikasi diri sebagai mediator. Penelitian ini menunjukkan koefisien terbesar antar kedua variabel berada dijalur langsung yaitu keterlibatan orang tua dan motivasi berprestasi. Efikasi diri sebagai mediator hanya berperan kecil sebagai perantara antara keterlibatan orang tua dan motivasi beprestasi, sehingga keterlibatan orang tua akan lebih mempengaruhi motivasi berprestasi. Selain itu, peran mediasi parsial dari efikasi diri tersebut menunjukkan adanya faktor lain yang berkemungkinan juga berpengaruh signifikan terhadap motivasi berprestasi. Faktor-faktor tersebut misalnya adalah kepuasan diri atau identitas diri, yang tidak diteliti dalam penelitian ini. Saran bagi peneliti selanjutnya adalah agar mereka menguji peran faktor-faktor lain tersebut.

Hasil-hasil penelitian ini memberikan sejumlah implikasi. Bagi keluarga, menghadirkan keterlibatan orang tua secara utuh dengan memperhatikan proses kegiatan akademik siswa dari rumah adalah hal yang sangat penting. Keterlibatan orang tua dalam proses kegiatan akademik siswa terejawantah dengan cara menjalankan komunikasi yang hangat, memberikan contoh yang baik terhadap indvidu siswa seperti gemar membaca, dan memberikan saran yang baik atas kegiatankegiatan yang dilakukan siswa di sekolah sehingga motivasi berprestasi siswa menjadi lebih baik.

\section{Daftar Pustaka}

Antawati, D. (2017). Peran orangtua dalam menumbuhkan intensi berwirausaha pada anak. Ekspektra, Jurnal Manajemen dan Bisnis, 1 (1), 46-54. DOI: http://dx.doi.org/10.25139/ekt.v1i 1.87

Badan Pusat Statistik Kabupaten Magetan. (2016). Angka partisipasi sekolah (APS) dan kelompok usia sekolah tahun 20082013. Diunduh dari https://magetankab.bps.go.id/statictable/ 2016/01/21/70/angka-partisipasisekolah-aps-dan-kelompok-usiasekolah-tahun-2008---2013-persen-.html

Bandura, A. (1989). Human agency in social cognitive theory. American Psychologist, 44(9), 1175-1184. https://psycnet.apa.org/doi/10.1037/0003066X.44.9.1175 
Bandura, A. (1992). Social cognitive theory of self-regulation. Organizational Behavior and Human Decision Processes, 50, 248$28 . \quad$ https://doi.org/10.1016/07495978(91)90022-L

Bandura, A. (1997). Self-efficacy. Harvard Mental Health Letter, 13(9), 4-7.

Bempechat, J., \& Shernoff, D. J. (2012). Parental influences on achievement motivation and student engagement. In S. L. Christenson, A. L. Reschly, \& C. Wylie (Eds.), Handbook of research on student engagement (pp. 315-342). New York, NY, US: Springer Science. doi:10.1007/978-1-4614-20187_15

Bloom, B. S. (1956). Taxonomy of educational objectives: Handbook 1, Cognitive domain. New York: David McKay.

Bong, M., Cho, C., Ahn H. S., \& Kim, H. J. (2012). Comparison of self-beliefs for predicting student motivation and achievement. J. Education Res. 105, 336352.

https://doi.org/10.1080/00220671.2011.62 7401

Caprara, G. V., Di, G. L., Pastorelli, C., \& Einsenberg, N. (2013). Mastery of negative affect: A hierarchical model of emotional self-efficacy beliefs. Psychological Assesment, 25(1), 105. doi: 10.1037/a0029136

Charlotte, D. (2014). Teacher evaluation and development in the common core era where it all began. In C. Danielso (Ed.), ASSD annual conference, March 16, 2014. Los Angeles, California: The Danielson Group.

Clark-Carter, D. (2010). Quantitative psychological research: The complete student's companion ( $3^{\text {rd }}$ edition). Psychology Departement. Staffords University. New York: Psychology Press.

Creswell, W. J. (2014). Research design: Pendekatan kualitatif, kuantitatif, dan mixed. Yogyakarta: Pustaka Pelajar.
Deci, E. L., \& Ryan, R. M. (2000). The "what" and "why" of goal pursuit: Human human needs and the self determination of behavior. Departement of Psychology: University of Rocheseter.

Doménech-Betoret, F., Abellán-Roselló, L., Gómez-Artiga, A. (2017). Self-efficacy, satisfaction, and accademic acchievement: The mediator role of students' expectancy-value beliefs. Frontiers in Psychology, 8, (1193), 1-12. https://doi.org/10.3389/fpsyg.2017.01193

Doménech-Betoret, F., Gómez-Artiga, A., \& Lloret-Segura, S. (2014). Personal variables, motivation and avoidance learning strategies in undergraduate students. Learn. Individ. Differ. 35, 122129.

https://doi.org/10.1016/j.lindif.2014.06.00 7

Dumont, H., Trautwein, U., Lüdtke, O., Neumann, M., Niggli, A., \& Schnyder, I. (2012). Does parental homework involvement mediate the relationship between family background and educational outcomes? Contemporary Educational Psychology, 37,(1), 55-69. https://doi.org/10.1016/j.cedpsych.2011.0 9.004

Dweck, C. S. (2006). Mindset: The new psychology of success. New York: Random House.

Eccles, J. S. (2005). Subjective task values and the Eccles et al. model of achievement related choices. In A. J. Elliot \& C. S. Dweck (Eds.), Handbook of competence and motivation (pp. 105-121). New York: Guilford.

Eccles, J. S., Wigfield, A., \& Schiefele, U. (1998). Motivation to succeed. .Handbook of child psychology (pp. 1017-1095). New York: Wiley.

Eccles, S. C., Wigfield. A., Reuman, B., Flanagan. (1993). Development during adolescence: The impact of stage environment fit on adolescents' 
experiences in schools and families. American Psychology lsl, 48, 90-97. https://psycnet.apa.org/doi/10.1037/0003066X.48.2.90

Gafor, A. (2014). Construction and validation of scale of parenting style. Guru Journal of Behavioral and Social Sciences, 2(4), 315-323. Diunduh dari https://files.eric.ed.gov/fulltext/ED55315 4.pdf

Gagne, M., \& Deci, E. L. (2005). Self determination theory and work motivation. Journal of Organizational Behaviour, 26, 331-362. https://doi.org/10.1002/job.322

Gerintya, S. (2019, Mei 02). Indeks pendidikan Indonesia kalah dari negara Asean lain, hanya unggul dari Kamboja, Laos, dan Myanmar.Tirto.co.id. Diunduh dari https://tirto.id/indeks-pendidikanindonesia-rendah-daya-saing-pun-lemahdnvR

Gonzalezz-DeHass, A. R., Willems, P. P., \& Holbein, M. F. D. (2005). Examining the relationship between parental involvement and student motivation. Educational Psychology Review, 17(2), 99-123. doi: 10.1007/s10648-005-3949-7

Green, J., Nelson, G., Martin, A. J., \& Marsh, H. (2006). The causal ordering of selfconcept and academic motivation and its effect on academic achievement. International Education Journal, 7(4), 534-546. Diakses dari https://files.eric.ed.gov/fulltext/EJ854309. pdf

Grolnick, W. S. (2016). Parental involvement and children's academic motivation and achievement. Building autonomous learners. Building autonomous learners perspective from research and practing using self determination-theory. New York: Spinger.

Grolvick, W. S. (2015). Mothers' motivation for involvement in their children's schooling: Mechanisms and outcomes.
Motivation And Emotion, 39(1), 63-73. doi:10.1007/s11031-014-9423-4

Hayes, A. F., \& Preacher, K. J. (2014). Statistical mediation analysis with a multicategorical independent variable. British Journal of Matematical and Statistical Psychology, 67(3), 451-470. https://doi.org/10.1111/bmsp.12028

Hill, N. E., \& Taylor, L. C. (2004). Parental school involvement and children's academic achievement: Pragmatics and issues. Current Directions in Psychological Science, 13, 161-164. doi: 10.1111/j.0963-7214.2004.00298.x

Hoang, T. N. (2007). The relationship between parenting and adolenscent motivation. International Journal of Whole Schooling, 3(2), 1-21. Diunduh dari

https://files.eric.ed.gov/fulltext/EJ84747 6.pdf

Jeynes, W. H. (2016). Meta-analysis on the roles of fathers in parenting: Are they unique? Marriage and Family Review, 52(7), 665-688. https://doi.org/10.1080/01494929.2016. 11571

Kim, S, W., \& Hill, N. E. (2015). Including fathers in the picture: A meta-analysis of parental involevement and students' academic achievement. Journal of Educational Psychology, 107(10), 919934.

https://psycnet.apa.org/doi/10.1037/edu 0000023

Klassen, R. M., \& Usher, E. L. (2010). Selfefficacy in educational settings: Recent research and emerging directions. In $\mathrm{T}$. C. Urdan \& S. A. Karabenick (Eds.), Advances in motivation and achievement. The decade ahead: Theoretical perspectives on motivation and achievement (pp. 1-33). Bingley, UK: Emerald Publishing Group.

Kusurkar, R. A., Ten Cate, T. J., Asperen, M. V., \& Croiset, M. V. (2011). Motivation 
as an independent and a dependent variable in medical education: A review of the literature. Medical Teacher, 33, E242-E262.

https://doi.org/10.3109/0142159X.2011.5 58539

Liu, F., Black, E., Algina, J., Cavanaugh, C., \& Dawson., K. (2010). The validation of one parental involvement measurement in virtual schooling. Journal of Interactive Online Learning, 9, (2), 105-132. Diunduh dari https://pdfs.semanticscholar.org/b7bb/b6c 862fc86b10d808360217b3635f4e5aedd.p df

Lv., Bo, Zhou, H., Liu, C., Guo, X., Liu, J., Jiang, K., Liu, Z., \& Luo, L. (2018). The relationship between parental involvement and children's self-efficacy profiles: A person-centered approach. Journal of Child and Family Studies. https://doi.org/10.1007/s10826-018-12016

Maehr, M. L., \& Zusho, A. (2009). Achievement goal theory: The past, present, and future. In K. R. Wentzel \& A. Wigfield (Eds.), Handbook of motivation at school (pp. 77-104). New York: Routledge.

Marvianto, R. D., \& Widhiarso, S. (2018). Adaptasi dan evaluasi properti psikometris academic motivation scale (AMS) dalam versi Bahasa Indonesia (Doctoral dissertation, Universitas Gadjah Mada). Diunduh dari http://etd.repository.ugm.ac.id/index.php? act=view\&buku_id=159424\&mod=peneli tian_detail\&sub=PenelitianDetail\&typ=ht $\mathrm{ml}$

McHarg, J., Mattick, K. M., \& Knight, L. V. (2007). Why people apply to medical school: Implications for widening participation activities. Med Educ 41, 815-821. https://doi.org/10.1111/j.13652923.2007.02798.x
Moller, A. C., Friedman, R., \& Deci, E. L. (2006). A self-determination theory perspectives on the interpersonal and intrapersonal aspects of self-esteem. In M. H. Kernis (Ed.), Self-esteem issues and answers: A sourcebook of current perspectives (pp. 125-131). Philadelphia, PA: Psychology Press.

Muris, P. (2001). A brief questionnaire for measuring self-efficacy in youths. Journal of Psychopathology and Behavioral Assessment, 23(3), 145-149. https://doi.org/10.1023/A:10109611196 08

Newman, B. M., Newman, P. R., Griffen, S., O'Connor, K., \& Spas, J. (2007). The relationship of social support to depressive symptoms during the transition to high school. Adolescence, 42(167), 441-459. Diunduh dari https://www.researchgate.net/publication/ 5801166_The_relationship_of_social_sup port_to_depressive_symptoms_during_th e_transition_to_high_school

Omar, R., Ahmad, N. A., Hassan, S. A., dan Roslan, S. (2017). Parental involvement and achievement motivation: Association with students' achievement in vocational colleges, Malaysia. International Journal of Academic Research in Business and Social Sciences. http://dx.doi.org/10.6007/IJARBSS/v7i14/3648

Peiffer, Garry Ed. D. (2015). The effect of selfefficacy on parental involvement at the secondary school level. University of Pittsburg.

Pintrich, P.R., \& Schunk, D.H. (1996). Motivation in education: Theory, research and applications (2nd ed.). Englewood Cliffs, NJ: Merrill Company.

Pomerantz, E. M., Moorman, E. A., \& Litwack, S. D. (2007). The how, whom, and why of parents' involvement in children's academic lives: More is not always better. Review of Educational Research, 77, (3), 
373-410.

https://doi.org/10.3102\%2F00346543030 5567

Schiefele, U. (2009). Situational and individual interest. In K. R. Wentzel \& A. Wigfield (Eds.), Handbook of motivation in school (pp. 197-223). New York: Taylor Francis.

Schuler, H., Thornton, G. C., Frintrup, A., \& Mueller-Hanson, R. (2002). Achievement motivation inventory (AMI). New York: Hans Huber Publishers.

Schunk, D. H. (2003). Self-efficacy for reading and writing: influence of modelling, goal setting, and self-evaluation. Reading and Writing Quarterly: Overcoming Learning Difficulties, $\quad 19(2), \quad$ 159-172. https://doi.org/10.1080/10573560308219

Schunk, D. H., \& Zimmerman, B. J. (2006). Competence and control beliefs: Distinguishing the means and ends. In P.A. Alexander \& P.H. Winne (Eds.), Handbook of educational psycholoby (pp. 349-367). Mahwah, NJ: Erlbaum.

Schunk, D. H., Pintrich, P. R., \& Meece, J. L. (terjemahan: Ellys Tjo). (2012). Motivasi dalam pendidikan: Teori, penelitian, dan aplikasi. Jakarta: Indeks.

Uduji, J. I., \& Ankeli, M. O. (2013). Needs for achievement, affiliation, and power: The possible sales manager's actions for exceptional salesforce performance. Research Journal of Finance and Accounting, 4, (9), 96-104. Diakses dari https://www.iiste.org/Journals/index.php/ RJFA/article/view/6713/7122

Vallerand, R. J., Pelletier L. G, Blais M. R., Biere N. M, Senecal C, \& Vallieres, E. F. (1992). On the assessment of intrinsic, extrinsic, and amotivation in education: Evidence on the concurrent and construct validity of the academic motivation scale.
Educational
and
Psychology
Measurement
$53,(1)$,
159-172.
https://doi.org/10.1177/001316449305300
1018

Vallerand, R. J., \& Ratelle, C. F. (2004). Intrinsic and extrinsic motivation: A hierarchical model. In: Deci E.L, \& Ryan R. M. (Eds.), Handbook of selfdetermination research (pp. 37-63). New York: University Rochester Press.

Wang, J., \& Zhang, Q. (2010). The relationship between career decisionmaking self-efficacy and achievement motivation of college students. Ludong University Journal (Philosophy and Social Sciences Edition), 27, (2), 90-93.

Wigfield, A., \& Eccles, J. S. (1992). The development of achievement task values: A theoretical analysis. Developmental Review, 12, 265-310. https://doi.org/10.1016/02732297(92)90011-P

Wigfield, A., \& Eccles, J. S. (2000). Expectancy-value theory of achievement motivation. Contemporary Educational Psychology, 25(1), 68-81. https://doi.org/10.1006/ceps.1999.1015

Wigfield, A., Eccles, J. S., Fredricks, J. A., Simpkins, S., Roeser, R. W., \& Schiefele, U. (2015). Development of achievement motivation and engangement. Handbook of child psychology and developmental science, 3, (16), 1-44. doi: 10.1002/9781118963418.childpsy316

Zimmerman, B. J., Bandura, A., \& MartinezPons, M. (1992). Self-motivation for academic attainment: The role of selfefficacy beliefs and personal goal setting. American Educational Research Journal, 29(3), 663-676. https://doi.org/10.3102\%2F00028312029 003663 